\title{
Chemical composition, toxicity, and repellence of plant essential oils against Diaphorina citri (Hemiptera: Liviidae)
}

\author{
Edgar Eduardo Mendoza-García ${ }^{1}$, Laura Delia Ortega-Arenas ${ }^{1 *}$, Miguel Ángel Serrato-Cruz ${ }^{2}$, \\ Juan Antonio Villanueva-Jiménez ${ }^{3}$, J. Isabel López-Arroyo ${ }^{4}$, and Rafael Pérez-Pacheco ${ }^{5}$ \\ ${ }^{1}$ Colegio de Postgraduados, Campus Montecillo, 56230, Montecillo, Texcoco, Estado de México, México. \\ "Corresponding author (ladeorar@colpos.mx). \\ ${ }^{2}$ Universidad Autónoma Chapingo, Departamento de Fitotecnia, 56230, Chapingo, Texcoco, Estado de México, México. \\ ${ }^{3}$ Colegio de Postgraduados, Campus Veracruz, 91690, Veracruz, Veracruz, México. \\ ${ }^{4}$ Instituto Nacional de Investigaciones Forestales, Agropecuarias y Pesqueras, Campo Experimental General Terán, 64700, General \\ Terán, Nuevo León, México. \\ Instituto Politécnico Nacional, Centro Interdisciplinario de Investigación para el Desarrollo Integral Regional, Unidad Oaxaca, 71230 , \\ Xoxocotlán, Oaxaca, México.
}

Received: 29 January 2019; Accepted: 17 June 2019; doi:10.4067/S0718-58392019000400636

\begin{abstract}
Diaphorina citri Kuwayama (Hemiptera: Liviidae) is an invasive species in America and is the main vector of the pathogen associated with Huanglongbing, a deadly disease of citrus plants in the world. The management of such a problem includes the intensive use of insecticides to reduce vector populations and risk of pathogen transmission. As an alternative to synthetic insecticides to control $D$. citri, the present study determined the chemical composition of diverse plant essential oils and assessed the toxicity and repellency of oil extracts against $D$. citri. Their chemical composition and abundance were determined by gas chromatography coupled to mass spectrometry. Adults and nymphs were exposed to leaf citrus discs treated by spraying or immersion with different oil extract concentrations. Repellency was assessed by exposing adults to treated leaves in experimental arenas and determining the number of insects remaining on the leaf after different time periods compared with the control. The main oil compounds in the tested plants were anethole, verbenone, 4-ethyl-4-methyl-1-hexene, 4-allylanisole, and trans-tagetone. Oils from Rosmarinus officinalis L. and Schinus molle L. caused no repellent or insecticide effects on D. citri. In contrast, oil extracts from the Foeniculum vulgare Mill. and Tagetes species were toxic and/or repellent for both adults and nymphs. There was a positive relationship between toxicity and concentration. Oil extracts from Tagetes lucida, T. coronopifolia, and T. terniflora were repellent (> 92\%) at $40 \mathrm{mg}$ $\mathrm{mL}^{-1}$; this was correlated with the concentration and decreased over time. Essential oils extracts from the Tagetes species could represent a potential defense that could be integrated into the management of $D$. citri.
\end{abstract}

Key words: Citrus, Huanglongbing, pest management, repellency, Tagetes, toxicity.

\section{INTRODUCTION}

Diaphorina citri Kuwayama (Hemiptera: Liviidae) is a major pest of citrus plants because of its ability to transmit the Candidatus Liberibacter spp. bacteria, which are associated with Huanglongbing (HLB), a destructive citrus disease found worldwide; vector control is crucial in managing it (Bové, 2012). The chemical control of D. citri is the principal tactic to reduce HLB dispersal in citrus orchards (Stansly and Qureshi, 2007). However, the over-reliance on conventional chemical products and the high concentrations being used have negatively affected populations of natural enemies and 
could lead to insect resistance (Tiwari et al., 2012; García-Méndez et al., 2016). For these reasons, there is a currently growing interest in using plant extracts and biopesticides to manage D. citri (Mann et al., 2012; Regnault-Roger et al., 2012; Mendoza-García et al., 2015). An advantage of plant extracts is their broad spectrum activity; extracts have different modes of action, including repellency and antifeedant activities, molting and cuticle disruption, growth and fecundity retardation, oviposition inhibition, and embryonic development disruption (Mafra-Neto et al., 2015). Due to the rapid action of these natural chemicals against insects and mites, it these compounds have been reported to possess neurotoxic effects that especially affect octopamine pathways and gamma-aminobutyric acid (GABA)-gated chloride ion channels (Isman et al., 2008). Furthermore, they are biodegradable and nontoxic to humans and other mammals (Mann et al., 2012; Regnault-Roger et al., 2012).

Although Mexico's plant diversity is rich, the biological properties of many plants are still unknown; these could probably have potential to control D. citri (Serrato et al., 2008; Mendoza-García et al., 2015). Some species from the Apiaceae, Asteraceae, Brassicaceae, and Piperaceae families have been identified as promising sources of compounds with pesticide properties (Mafra-Neto et al., 2015). In Asteraceae, for example, Tagetes (marigold) is an important genus native to Mexico and Central America with effective species against bacteria, fungi, nematodes, mites, and insects (Camarillo et al., 2009; Mendoza-García et al., 2014; 2015) among other pest and disease organisms. Oil extracts from Tagetes species contain active ingredients, such as trans-anethole, allylanisole, $\beta$-caryophyllene, ocimenone, piperitone, and tagetone, that have toxic, repellent, and/or inhibitive effects on insect reproduction and growth (Xu et al., 2012). Approximately 30 Tagetes species exist in Mexico, which is half of the recorded species in America (Serrato et al., 2008). Despite such diversity, there are few studies on the biological activity of the substances they contain (Serrato et al., 2008; Camarillo et al., 2009; Mendoza-García et al., 2015).

The Apiaceae also harbor species that contain essential oils with pesticide properties. For example, Foeniculum vulgare Mill. (fennel) is rich in compounds such as phenylpropanoids, monoterpenes, and sesquiterpenes; trans-anethole is its most abundant compound (Shamkant et al., 2014). Extracts from F. vulgare are effective against different insects (Shamkant et al., 2014). In Lamiaceae, rosemary (Rosmarinus officinalis L.) is another species in which the essential oil has insecticide properties; it is frequently the active ingredient in several commercial insecticides (Isman et al., 2008). Nine major terpenoid constituents of rosemary oil have been quantified by gas chromatography-mass spectrometry , and camphor, 1,8-cineole, $\alpha$-pinene, and $\beta$-pinene are the major constituents. Recent research showed synergistic interactions between the two major insecticide constituents of rosemary oil, that is, 1,8-cineole and camphor, against the cabbage looper, Trichoplusia ni (Hübner) (Tak and Isman, 2015). The essential oil from S. molle leaves and fruits has also been demonstrated as a strong repellent and insecticide; these effects are mainly associated with cis-menth-2-en-1-ol and transpiperitol (López et al., 2014).

Although some studies have been conducted about the effect of plant essential oils against D. citri (Mann et al., 2012; Mafra-Neto et al., 2015; Mendoza-García et al., 2015), the present study was undertaken to determine the chemical composition of essential oils from F. vulgare, Rosmarinus officinalis (Lamiaceae), Schinus molle L. (Anacardiaceae), Tagetes coronopifolia Willd., T. lemmonii A. Gray, T. lucida Cav., and T. terniflora Kunth (Asteraceae) and to evaluate their potential toxic and repellent effects against $D$. citri nymphs and adults.

\section{MATERIALS AND METHODS}

All bioassays to evaluate the toxic and/or repellent effects of essential oils were conducted in the Laboratory of Insect Vectors at the Colegio de Postgraduados, Campus Montecillo, in Texcoco, Mexico, with insects reared under controlled greenhouse conditions.

\section{Insect rearing}

The Diaphorina citri Kuwayama (Hemiptera: Liviidae) strain was established in 2009 from approximately 2000 adults (1:1, male:female) collected from orange (Citrus $\times$ sinensis (L.) Osbeck; Rutaceae) 'Valencia' orchards and jasmineorange (Murraya paniculata (L.) Jack; Rutaceae) plants in Cazones de Herrera, Veracruz, Mexico, and then maintained under continuous culture on orange plants $(C . \times$ sinensis $)$ in an isolated greenhouse. 
For the experiments, adults were introduced into entomological cages $(60 \times 40 \times 60 \mathrm{~cm})$ covered inside with fine mesh and in which 4-mo-old $C . \times$ sinensis plants in plastic pots $(30 \times 30 \mathrm{~cm}$ containing a mixture of vermicompost, leaf soil, and vermiculite in a 3:2:1 ratio) were previously placed. Adults were allowed to oviposit on these plants for $1 \mathrm{wk}$; they were subsequently removed with a manual vacuum. The remaining nymph-infested plants were transferred to clean cages and incubated under greenhouse conditions $\left(25 \pm 5^{\circ} \mathrm{C}\right.$ and $12: 12 \mathrm{~h}$ photoperiod) until the nymphs reached the third instar or emerged as adults.

\section{Extraction of potential plant active ingredients}

In 2012, plots of Tagetes coronopifolia (locally known as 'sonajilla') from Santa María Tecuanulco, Texcoco, Mexico, $T$. lemmonii (locally known as 'rudilla') from Sierra de Mazatlán, Sonora, Mexico, T. lucida (locally known as 'pericón') from San Pablo Ixayoc, Texcoco, Mexico, and T. terniflora from Los Altos de Chiapas, Mexico, were established at the

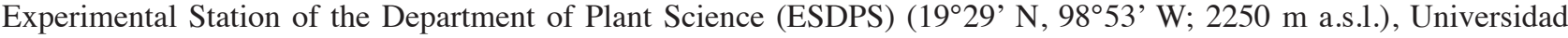
Autónoma Chapingo, State of Mexico. Sowing was carried out under greenhouse conditions in polypropylene trays with 200 cavities for germination and maintained until the seedlings showed the first pair of true leaves ( $35 \mathrm{~d})$. The trays were watered every third day with Peters Professional fertilizer solution 1\% NPK (20-20-20+TE [trace elements]) (ICL Specialty Fertilizers, Dublin, Ohio, USA). Seedlings were transplanted during June under field conditions at the ESDPS in rows with $75 \mathrm{~cm}$ spacing and $20 \mathrm{~cm}$ spacing between plants. Agronomic tasks included mechanical weed control and irrigation prior to transplanting. In October, all of the aboveground parts of the flowering plants were harvested and prepared for oil extraction.

Foeniculum vulgare Mill. plants were collected from a plot established in 2010 at the ESDPS, while fresh cut Rosmarinus officinalis L. plants were acquired at a local market in Ecatzingo, Mexico. Material from Schinus molle L. was obtained from 10-yr-old trees at the ESDPS. In all cases, plants were selected only if they were abundant and at the flowering stage. Six species were identified by Ernestina Cedillo Portugal, curator of the "José Espinosa Salas" herbarium at the Universidad Autónoma Chapingo, and one species was identified by Jesús Sánchez Escalante, curator of the herbarium at the Universidad Autónoma Sonora; they used the Calderón and Rzedowski (2001) taxonomic keys and compared the species with existing specimens in the herbarium. Voucher numbers were assigned as T. coronopifolia Willd. 2568, T. lucida Cav. 13201, T. terniflora Kunth 31586, F. vulgare 22021, R. officinalis 37015, S. molle 12031, and T. lemmonii A. Gray 9181.

For oil extraction, approximately $250 \mathrm{~kg}$ of fresh tissue from each plant were macerated with a silage chopper. Oils were immediately extracted by hydrodistillation in a stainless steel distiller $(1 \times 1.2 \mathrm{~m})$ with a $300 \mathrm{~kg}$ capacity. Distillation time was approximately $3 \mathrm{~h}$, followed by condensation of 200 to $400 \mathrm{~mL}$ extract. The oils were stored in amber-colored glass jars with covers and refrigerated at $4{ }^{\circ} \mathrm{C}$.

\section{Chemical analyses}

Essential oil composition was analyzed by gas chromatography coupled to mass spectrometry (GC-MS) using a GC 7890A (Agilent Technologies, Santa Clara, California, USA) with a 5975C Inert MSD mass detector, electronic impact $(70 \mathrm{eV})$. An RTX-5MX column (diphenyl-dimethylpolysiloxane (5:95), $30 \mathrm{~m} \times 0.25 \mathrm{~mm}$ internal diameter $\times 0.25 \mu \mathrm{m})$ was used. The injector and detector were set at 250 and $300^{\circ} \mathrm{C}$. Oven temperature was initially $70{ }^{\circ} \mathrm{C}$ and maintained for $1 \mathrm{~min}$; the temperature was then programmed to rise to $250^{\circ} \mathrm{C}$ at a rate of $20^{\circ} \mathrm{C} \min ^{-1}$. Helium was used as the carrying gas at a flow rate of $1 \mathrm{~mL} \mathrm{~min}^{-1}$. Diluted samples $(1 \mu \mathrm{L})$ were manually injected $(1 / 100$ in acetone $\mathrm{v} / \mathrm{v})$ in split mode. Quantitative data were electronically obtained from the area percentage of the chromatographic peak. The detected mass range was 35-500 m/z. $n$-Alkanes were used as references to calculate the Kovats index. Three processed samples were measured to identify the components by comparing the relative retention times and mass spectra using the National Institute of Standards and Technology (NIST) database of the GC-MS system.

\section{Plant essential oil biological activity}

Each of the oil extracts was resuspended in distilled water to produce a $10 \%(\mathrm{w} / \mathrm{v})$ solution from which further dilutions were done to obtain samples ranging from 10 to $0.001 \mathrm{mg} \mathrm{mL}^{-1}$. These dilutions were used in a preliminary experiment (biological response window) to detect insect mortality or repellency rates in the 0 to 100 range and determine the 
concentrations to use in each bioassay. Distilled water (control) was always included. In all treatments, including the control, $0.01 \%$ Tween 20 was added as a surfactant before application.

Only the oil extracts that exhibited significant biological activity $(\geq 40 \%)$ in the preliminary experiments were selected and used in both nymph and adult toxicity bioassays and the detailed assessment of adult repellency. The rest were excluded from the evaluation. Seven or eight concentrations that satisfactorily represented the entire range of mortality or repellence were selected in each bioassay.

\section{Nymph bioassay}

The toxic effect of the oil extracts on $D$. citri nymphs was evaluated following the method described by Mendoza-García et al. (2015) with some slight modifications. A single orange leaf disc $(4.0 \mathrm{~cm} \varnothing)$ was submerged in each essential oil solution/concentration combination for $5 \mathrm{~s}$ and then left to dry at room temperature $\left(25 \pm 3{ }^{\circ} \mathrm{C}\right)$ on a mesh surface with the adaxial surface facing upward. Control leaves were only dipped in water with $0.01 \%$ Tween 20 solution. Each dried leaf disc was then placed with the abaxial side facing upward on a Petri dish $(4.0 \mathrm{~cm} \varnothing)$ covered with an organza screen to allow ventilation; to prevent desiccation, $1.5 \%$ water agar was added at the bottom of the dish. Each Petri dish was an experimental unit. Some 10 to 15 third instar nymphs were then introduced on each disc; the Petri dishes were closed and placed on trays and kept under controlled conditions $\left(25 \pm 3{ }^{\circ} \mathrm{C}, 12: 12 \mathrm{~h}\right.$ photoperiod). Mortality was recorded after $24 \mathrm{~h}$ under a stereoscopic microscope (10X). An individual was considered dead when it showed desiccation or dehydration symptoms or it did not move when touched with the bristles of an entomological brush (size 000). Five replicates were performed for each concentration.

\section{Adult bioassay}

To assess the toxic effect of oil extracts on $D$. citri adults, replicated groups of 20 mixed-sex adults aged 3 to $6 \mathrm{~d}$ were first starved for $2 \mathrm{~h}$. Prior to the spray application of the essential oil solutions, each group of adults was anesthetized with $\mathrm{CO}_{2}$ for approximately $2 \mathrm{~min}$ (Mann et al., 2012) and transferred with an entomological brush (size 000) to an orange leaf disc placed with the abaxial side facing upward in a Petri dish $(4.0 \mathrm{~cm} \varnothing)$, as described above for the nymph bioassay. Each group was sprayed three times with a manual $5 \mathrm{~mL}$ atomizer for a total of $1.5 \mathrm{~mL}$ of the extracted oil solution. Petri dishes were closed and maintained under controlled conditions $\left(25 \pm 3^{\circ} \mathrm{C}, 12: 12 \mathrm{~h}\right.$ photoperiod). For each extract/concentration combination and control, 20 mixed-sex adults aged 3 to $6 \mathrm{~d}$ were used and five replicates were performed. Mortality was recorded after 24 and $48 \mathrm{~h}$.

\section{Repellency bioassay}

To assess the potential repellent effect of the oil extracts on D. citri adults, experimental arenas were constructed (Figure 1). Each arena consisted of an inverted transparent $250 \mathrm{~mL}$ polypropylene cup with a lid and four holes: one small lateral hole sealed with a removable plug was used to introduce the $D$. citri adults, whereas one hole in the base and two more in the sides were covered with fine mesh to allow ventilation. Before each experimental arena was closed, a treated or a control orange leaf was introduced. Petioles were fixed in $2 \mathrm{~mL}$ glass vials containing tap water to maintain leaf turgor. Treated leaves had previously been submerged for $5 \mathrm{~s}$ in the test substance and then dried as previously described; control leaves were submerged in a $0.01 \%$ Tween 20 solution (Figure 1). In each experimental arena, 20 D. citri adults aged 3 to $6 \mathrm{~d}$ and starved for $2 \mathrm{~h}$ were introduced through the lateral hole and the plug was replaced.

Repellency was determined as the difference in the number of insects settled on control leaves compared with treated leaves at 4, 5, 6, and $24 \mathrm{~h}$ after their introduction and expressed as a percentage ( $20=100 \%$ in each replicate). Each arena represented an experimental unit. For each concentration, 20 mixed-sex adults aged 3 to $6 \mathrm{~d}$ were used and five replicates were performed.

\section{Statistical analyses}

Mortality in the control was less than $12 \%$ in all the experiments. Treatment mortality and repellence values were corrected by Abbott's equation with values obtained in the control. All analyses were performed with the SAS version 9.0 (SAS Institute, Cary, North Carolina, USA) software. The effects of the treatments on mortality of $D$. citri nymphs and adults were analyzed by the Kruskal-Wallis test and Tukey's test $(\mathrm{P} \leq 0.05)$. Furthermore, data were subjected to 
Figure 1. Bioassay arena used in the laboratory to evaluate the potential repellent effects of plant oil extracts on Diaphorina citri adults.

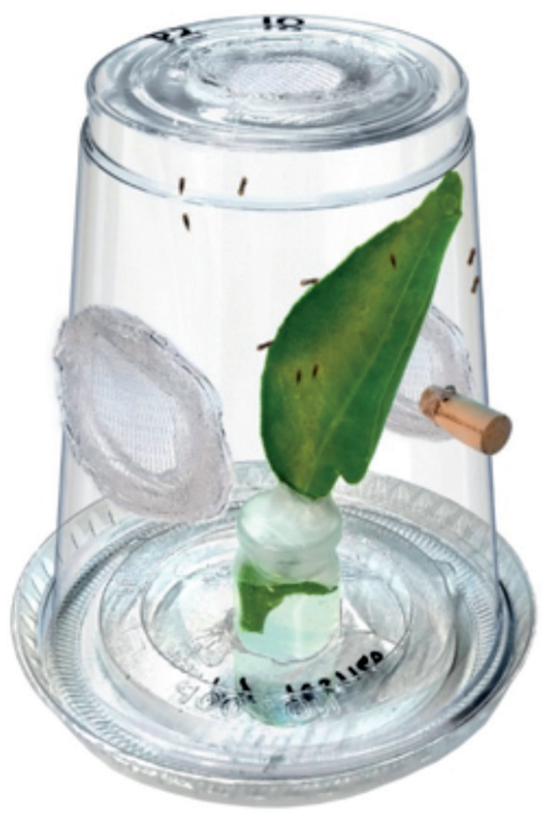

probit analysis to determine the log-dose response, slopes, and confidence intervals; the median lethal concentration $\left(\mathrm{LC}_{50}\right)$ and median repellence concentration $\left(\mathrm{RC}_{50}\right)$, both expressed in $\mathrm{mg} \mathrm{mL} \mathrm{mL}^{-1}$, were also calculated. To compare the repellence effect at each concentration, the repellence index (RI) was calculated by the formula $R I=2 G /(G+P)$ where $G$ is the percentage of insects settled on the treatment and $P$ is the percentage of insects settled on the control. The indices were classified as RI $=1$ for neutral concentration, $\mathrm{RI}<1$ for repellent concentration, and RI $>1$ for attractant concentration.

\section{RESULTS}

\section{Chemical analyses}

According to the fragmentation patterns, 18 to 31 compounds were identified in the seven essential oils (Table 1). Four main constituents accounted for more than $54 \%$ of the total oil. There were some similarities among the chemical compositions of the studied substances, mainly in the Tagetes species. These plants had $\beta$-ocimene, 4-ethyl-4-methyl-1hexene, anethole, trans-tagetone, cis-tagetone, verbenone, cis-verbenone, and $\beta$-caryophyllene in common (Table 1). As in other compositions, (cis-trans) tagetones, $\beta$-ocimenones, and trans-anethole dominated the chemical profile of the oils, indicating that these compounds are the main final components of biosynthesis.

\section{Plant essential oil biological activity}

In preliminary bioassays, oils from $S$. molle and $R$. officinalis had no biological activity against $D$. citri. There were also no toxic effects of T. lucida oil on nymphs and T. lemmonii oil on adults. Finally, oil extracts from F. vulgare and T. lemmonii showed no repellency against $D$. citri. These species were excluded from further detailed assessment (data not shown).

\section{Nymph and adult mortality}

The essential oils from T. coronopifolia $\left(\mathrm{X}^{2}=37.19 ; \mathrm{df}=7,39 ; \mathrm{P}<0.0001\right)$ and T. terniflora $\left(\mathrm{X}^{2}=37.50 ; \mathrm{df}=8,44 ; \mathrm{P}<\right.$ $0.0001)$ at a rate of $10 \mathrm{mg} \mathrm{mL}^{-1}$ caused $100 \%$ mortality of D. citri nymphs. Foeniculum vulgare $\left(\mathrm{X}^{2}=37.14 ; \mathrm{df}=7,39 ; \mathrm{P}\right.$ $<0.0001)$ and T. lemmonii $\left(\mathrm{X}^{2}=38.26 ; \mathrm{df}=8,44 ; \mathrm{P}<0.0001\right)$ produced $92 \%$ and $98 \%$ mortality, respectively. The $\mathrm{LC}_{50}$ values for the different oil extracts ranged from 0.05 to $0.21 \mathrm{mg} \mathrm{mL}^{-1}$. Tagetes lemmonii had the lowest $\mathrm{LC}_{50} \mathrm{value}(0.05$ $\left.\mathrm{mg} \mathrm{mL} \mathrm{m}^{-1}\right)$; it was therefore the most toxic, followed in descending order by T. coronopifolia $\left(0.11 \mathrm{mg} \mathrm{mL}^{-1}\right), F$. vulgare 
Table 1. Retention times and relative percentage of volatiles identified by gas chromatography coupled to mass spectrometry (GC-MS) from the aromatic plant essential oils.

\begin{tabular}{|c|c|c|c|c|c|c|c|c|c|}
\hline $\mathrm{Nr}$ & Compound & Rt & $\begin{array}{l}\text { Foeniculum } \\
\text { vulgare }\end{array}$ & $\begin{array}{l}\text { Rosmarinus } \\
\text { officinalis }\end{array}$ & $\begin{array}{l}\text { Schinus } \\
\text { molle }\end{array}$ & $\begin{array}{c}\text { Tagetes } \\
\text { coronopifolia }\end{array}$ & $\begin{array}{c}T . \\
\text { lemmonii }\end{array}$ & $\begin{array}{c}T . \\
\text { lucida }\end{array}$ & $\begin{array}{c}T . \\
\text { terniflora }\end{array}$ \\
\hline 1 & 2,3,5-Trimethylfuran & 3.23 & - & - & - & 0.83 & - & - & 1.10 \\
\hline 2 & 1,7,7-Trimethyltricyclo [2.2.1.0 $\left.0^{2,6}\right]$ heptane & 3.28 & - & - & 1.01 & - & - & - & - \\
\hline 3 & $\alpha$-Pinene & 3.39 & 14.21 & 12.13 & 4.63 & - & 0.26 & - & - \\
\hline 4 & Camphene & 3.56 & 0.12 & 5.90 & 6.63 & - & - & - & - \\
\hline 5 & $\beta$-Phellandrene & 3.78 & 0.33 & - & 0.59 & - & 0.47 & - & - \\
\hline 6 & $\beta$-Pinene & 3.85 & 3.46 & 5.64 & 2.70 & - & - & 2.09 & - \\
\hline 7 & $\beta$-Myrcene & 3.91 & 1.88 & 3.50 & 8.44 & - & 0.66 & - & - \\
\hline 8 & $\begin{array}{l}\text { Bicyclo[3,1,0]hexane, 4-methyl-1-(1-methylethyl)-, } \\
\text { didehydro deriv. }\end{array}$ & 4.14 & 17.14 & 7.11 & 27.74 & - & 0.91 & - & - \\
\hline 9 & $\alpha$-Terpinene & 4.27 & - & 1.47 & - & - & - & - & - \\
\hline 10 & o-Cymene & 4.36 & 2.33 & 2.29 & 2.58 & - & 0.35 & - & - \\
\hline 11 & D-Limonene & 4.42 & - & - & 11.06 & - & - & - & - \\
\hline 12 & $\beta$-Ocimene & 4.44 & 4.36 & - & - & 9.51 & 11.51 & 0.24 & 19.26 \\
\hline 13 & Eucalyptol & 4.48 & - & 22.29 & - & - & - & - & - \\
\hline 14 & Ocimene & 4.58 & 0.05 & - & - & - & - & 8.98 & - \\
\hline 15 & 4-Ethyl-4-methyl-1-hexene & 4.64 & - & - & - & 14.49 & 35.21 & 0.42 & 20.48 \\
\hline 16 & $\gamma$-Terpinene & 4.77 & 1.14 & 2.04 & - & - & - & - & - \\
\hline 17 & Cyclopropane, octyl- & 5.15 & - & - & - & 3.40 & - & 0.05 & - \\
\hline 18 & Carvenone & 5.16 & - & 0.84 & - & - & 1.33 & - & 2.29 \\
\hline 19 & Fenchone & 5.19 & 3.74 & - & - & - & - & - & - \\
\hline 20 & Linalool & 5.26 & - & 1.74 & - & 0.72 & - & 1.87 & - \\
\hline 21 & 3-Methylbut-2-enoic acid, 4-nitrophenyl ester & 5.43 & - & - & - & 0.85 & 0.23 & - & - \\
\hline 22 & 4-t-Pentylcyclohexene & 5.46 & - & - & - & 2.70 & - & - & - \\
\hline 23 & 2-Octen-4-ol, $(E)$ - & 5.47 & - & - & - & - & 0.22 & - & - \\
\hline 24 & 2,4,6-Octatriene, 2,6-dimethyl-, (E,Z)- & 5.62 & - & - & - & - & - & - & 0.69 \\
\hline 25 & 2-Dodecen-4-yne, $(E)$ - & 5.64 & - & - & - & 0.80 & - & - & - \\
\hline 26 & 2-Dodecen-4-yne, $(Z)$ - & 5.65 & - & - & - & - & 0.38 & - & - \\
\hline 27 & $\begin{array}{l}\text { 5-Isopropyl-3,3-dimethylene-2,3-methylene- } \\
\text { 2,3-dihydrofuran }\end{array}$ & 5.73 & - & - & - & - & 0.53 & - & 1.06 \\
\hline 28 & cis-Tagetone & 5.84 & - & - & - & 2.44 & 7.53 & - & 1.73 \\
\hline 29 & $N, N^{\prime}$-bis(2,6-Dimethyl-6-nitrosohept-2-en-4-one & 5.89 & - & - & - & 1.81 & - & - & - \\
\hline 30 & Trans-Tagetone & 5.95 & - & - & - & 9.37 & 21.79 & 0.03 & 28.65 \\
\hline 31 & (-)-Camphor & 5.99 & 0.06 & 24.05 & - & - & - & - & - \\
\hline 32 & Sorbic acid vinyl ester & 6.09 & - & - & - & 1.06 & - & - & 0.56 \\
\hline 33 & Terpene-4-ol & 6.37 & 0.08 & 1.32 & - & - & - & - & - \\
\hline 34 & Terpenol & 6.59 & - & 1.32 & - & - & - & - & - \\
\hline 35 & Isoanethole & 6.61 & 2.72 & - & - & - & - & - & - \\
\hline 36 & n-Decanal & 6.62 & - & - & - & - & 0.40 & - & - \\
\hline 37 & 4-Allylanisole & 6.63 & - & - & - & - & - & 36.01 & - \\
\hline 38 & 3,5-Heptadienal, 2-ethylidene-6-methyl- & 6.70 & - & - & - & 1.18 & - & - & 0.52 \\
\hline 39 & 4,4 Dimetil-ciclohexano-2-en-1-ol & 7.01 & 0.04 & - & - & - & - & - & - \\
\hline 40 & Verbenone & 7.02 & - & 0.95 & - & 30.74 & 1.72 & - & 2.85 \\
\hline 41 & cis-Verbenone & 7.10 & - & - & - & 13.26 & 1.70 & - & 13.83 \\
\hline 42 & p-Anisaldehyde & 7.33 & 0.25 & - & - & - & - & - & - \\
\hline 43 & Phenol, 2-ethyl-4,5-dimethyl- & 7.36 & - & - & - & 0.58 & - & - & 0.28 \\
\hline 44 & $\begin{array}{l}\text { 1,2-cis-1,5-trans-2,5-Dihydroxy-4-methyl-1- } \\
\text { (1-hydroxy-1-isopropyl)cyclohex-3-ene }\end{array}$ & 7.55 & - & - & - & - & - & - & 0.19 \\
\hline 45 & $\begin{array}{l}\text { 2-Cyclohexen-1-one, 3-methyl-6- } \\
\text { (1-methylethenyl)-, }(S) \text { - }\end{array}$ & 7.62 & - & - & - & 1.40 & - & - & 0.78 \\
\hline 46 & Anethole & 7.78 & 47.67 & - & 3.94 & 0.87 & 1.61 & 17.20 & 0.23 \\
\hline 47 & Bornyl acetate & 7.80 & - & 2.55 & - & - & - & - & - \\
\hline 48 & (6-Hidroxymethyl-2,3-dimethylphenyl)methanol & 7.94 & 0.04 & - & - & - & - & - & - \\
\hline 49 & 2-Methoxy-4-vinylphenol & 8.16 & - & - & - & 0.64 & - & - & - \\
\hline 50 & Eugenol & 8.74 & - & - & - & - & - & 0.05 & - \\
\hline 51 & Copaene & 9.02 & - & - & 0.65 & - & 0.24 & - & - \\
\hline 52 & (E)-Methyl cinnamate & 9.07 & - & 0.63 & - & - & - & - & - \\
\hline 53 & $\begin{array}{l}\text { 1H-Cyclopropa[a]naphthalene, 1a, 2,3,3a,4,5,67b- } \\
\text { octahydro-1,1,3a,7-tetramethyl-,[1aR-(1aa,3aa,7ba)]- }\end{array}$ & 9.14 & - & - & - & - & - & - & 0.82 \\
\hline 54 & $\beta$-Elemene & 9.21 & - & - & - & - & 0.36 & 0.26 & - \\
\hline
\end{tabular}


Continuation Table 1.

\begin{tabular}{|c|c|c|c|c|c|c|c|c|c|}
\hline $\mathrm{Nr}$ & Compound & Rt & $\begin{array}{l}\text { Foeniculum } \\
\text { vulgare }\end{array}$ & $\begin{array}{l}\text { Rosmarinus } \\
\text { officinalis }\end{array}$ & $\begin{array}{l}\text { Schinus } \\
\text { molle }\end{array}$ & $\begin{array}{c}\text { Tagetes } \\
\text { coronopifolia }\end{array}$ & $\begin{array}{c}T . \\
\text { lemmonii }\end{array}$ & $\begin{array}{c}T . \\
\text { lucida }\end{array}$ & $\begin{array}{l}T . \\
\text { terniflora }\end{array}$ \\
\hline 55 & $\begin{array}{l}\text { 2-(3-Isopropyl-4-methyl-pent-3-en-1-ynyl)-2- } \\
\text { methyl-cyclobutanone }\end{array}$ & 9.23 & - & - & - & - & - & - & 0.33 \\
\hline 56 & Dodecan-1-yl acetate & 9.28 & - & - & - & 1.30 & - & - & - \\
\hline 57 & Methyleugenol & 9.30 & - & - & - & - & - & 27.25 & - \\
\hline 58 & $\alpha$-Gurjunene & 9.48 & - & - & 1.16 & - & 0.39 & - & 0.19 \\
\hline 59 & $\beta$-Caryophyllene & 9.63 & - & 2.36 & 4.01 & 2.08 & 1.57 & 0.59 & 2.36 \\
\hline 60 & $\alpha$-Bergamotene & 9.74 & - & 0.06 & - & - & - & - & - \\
\hline 61 & $\alpha$-Caryophyllene & 10.05 & - & 0.30 & 1.11 & - & 0.36 & 0.10 & 0.32 \\
\hline 62 & (+)-Aromadendrene & 10.15 & - & - & 0.66 & - & - & - & - \\
\hline 63 & $\gamma$-Muurolene & 10.30 & - & - & 1.34 & - & 0.59 & - & - \\
\hline 64 & Germacrene D & 10.39 & - & - & 7.69 & - & 3.52 & 0.42 & - \\
\hline 65 & Isoeugenol methyl ether & 10.46 & - & - & - & - & - & 3.74 & - \\
\hline 66 & $\alpha$-Amorphene & 10.58 & - & - & 4.03 & - & 1.79 & 0.20 & 0.93 \\
\hline 67 & $\beta$-Bisabolene & 10.62 & - & - & - & - & - & - & 0.25 \\
\hline 68 & ठ-Cadinene & 10.78 & - & 0.06 & - & - & 2.69 & 0.10 & - \\
\hline 70 & $\begin{array}{l}\text { Naphthalene, 1,2,3,4,4a,5,6,8a-octahydro-7- } \\
\text { methyl-4-methyl-1-(1-methylethyl)-, (1a,4aa,8aa)- } \\
\text { Naphthalene, 1,2,3,5,8a-hexahydro-4,7- }\end{array}$ & 10.77 & - & - & 1.62 & - & - & - & - \\
\hline 71 & $\begin{array}{l}\text { dimethyl-1-(1-methylethyl)-, (1S-cis)- } \\
\text { Cyclohexanemethanol, 4-ethenyl-a,a,4- }\end{array}$ & 10.86 & - & - & 6.87 & - & - & - & - \\
\hline & trimethyl-3-(1-methylethenyl)-, [1R-(1a,3a,4b)]- & 11.28 & - & - & - & - & 0.23 & - & - \\
\hline 72 & Cis- and trans-Nerolidol & 11.32 & - & - & - & - & - & 0.03 & - \\
\hline 73 & $\beta$-Caryophyllene oxide & 11.66 & - & 0.46 & - & - & 0.27 & 0.12 & 0.17 \\
\hline 74 & tau-Muurolol & 12.40 & - & - & - & - & 0.51 & - & - \\
\hline 75 & $\alpha$-Cadinol & 12.52 & - & - & 1.54 & - & 0.69 & - & - \\
\hline 76 & $(+)$-Valeranone & 12.70 & - & - & - & - & - & 0.03 & - \\
\hline 77 & 2H-1-Benzopyran-2-one, 7-methoxy- & 13.23 & - & - & - & - & - & 0.12 & - \\
\hline & Total compounds & & 18 & 22 & 21 & 21 & 31 & 22 & 24 \\
\hline & Total & & 99.62 & 99.01 & 100 & 99.2 & 100 & 99.9 & 98.77 \\
\hline & Main compounds & & 83.38 & 65.58 & 54.93 & 68.0 & 76.04 & 89.44 & 82.22 \\
\hline
\end{tabular}

Identification was based on comparing retention times with standard and spectral data from Nist05 Libraries.

Rt: Retention times that are outside the retention times of the homologous series of C8-C18 alkenes (identified by mass spectrometry, MS); -: not identified.

$\left(0.19 \mathrm{mg} \mathrm{mL}^{-1}\right)$, and $T$. terniflora $\left(0.21 \mathrm{mg} \mathrm{mL}^{-1}\right)$. The confidence intervals corresponding to the $\mathrm{LC}_{50}$ values of the four essential oils overlapped, indicating that there were no differences among treatments. Results for the slope of the equation showed that oil extracts from T. coronopifolia and T. lemmonii were similar $(\mathrm{b}=0.8, \mathrm{P}<0.0001$ and $\mathrm{b}=0.7, \mathrm{P}<0.0001$, respectively); T. terniflora had the lowest value $(b=0.4, \mathrm{P}=0.0323)$ (Table 2$)$.

Oil extracts from $F$. vulgare $\left(\mathrm{X}^{2}=36.51 ; \mathrm{df}=7,39 ; \mathrm{P}<0.0001\right)$, T. coronopifolia $\left(\mathrm{X}^{2}=31.63 ; \mathrm{df}=6,34 ; \mathrm{P}<0.0001\right)$, and T. terniflora $\left(\mathrm{X}^{2}=36.18 ; \mathrm{df}=7,39 ; \mathrm{P}<0.0001\right)$ all caused $100 \%$ mortality of $D$. citri adults exposed for $24 \mathrm{~h}$ to a $100 \mathrm{mg} \mathrm{mL}^{-1}$ concentration. At a rate of $20 \mathrm{mg} \mathrm{mL}^{-1}$, the three essential oils also achieved $100 \%$ mortality after $48 \mathrm{~h}$ application. After a $24 \mathrm{~h}$ exposure, the oil extract from T. terniflora had the lowest $\mathrm{LC}_{50}$ value $\left(14.15 \mathrm{mg} \mathrm{mL}^{-1}\right)$, which represented the highest toxic effect, followed by $F$. vulgare $\left(14.93 \mathrm{mg} \mathrm{mL}^{-1}\right)$ and T. coronopifolia $\left(15.02 \mathrm{mg} \mathrm{mL}^{-1}\right)$. After a $48 \mathrm{~h}$ exposure, the $\mathrm{LC}_{50}$ values decreased considerably: F. vulgare $=8.31 \mathrm{mg} \mathrm{mL}^{-1}$, T. coronopifolia $=9.74 \mathrm{mg} \mathrm{mL}^{-1}$, and $T$. terniflora $=11.38 \mathrm{mg} \mathrm{mL}^{-1}$. As with the nymphs, confidence intervals for the three oils were overlapping, indicating that there were no differences in their toxic activity. All recorded slopes were greater than 1.0, indicating a uniform response to all the oil extracts (Table 3).

\section{Psyllid adult repellence}

There was a positive relationship between repellency and oil extract concentration from T. coronopifolia, T. lucida, and $T$. terniflora. A $92 \%$ repellency value was observed with $40 \mathrm{mg} \mathrm{mL}^{-1}$ in the T. coronopifolia extract after a $4 \mathrm{~h}$ exposure, and this value decreased over time. According to the RI values, a repellent effect was observed at $3.5 \mathrm{mg} \mathrm{mL}^{-1}(0.74 \pm 0.23)$, $1.0 \mathrm{mg} \mathrm{mL}^{-1}(0.90 \pm 0.09), 3.5 \mathrm{mg} \mathrm{mL}^{-1}(0.85 \pm 0.09)$, and $40 \mathrm{mg} \mathrm{mL}^{-1}(0.57 \pm 0.41)$ after 4, 5, 6, and $24 \mathrm{~h}$ of exposure, respectively (Table 4). The oil extract from T. lucida exhibited repellency levels greater than $95 \%$ at $40 \mathrm{mg} \mathrm{mL}^{-1}$ throughout 
Table 2. Mean mortality ( $\% \pm$ SD) of third instar Diaphorina citri nymphs $24 \mathrm{~h}$ after the application of four essential oils.

\begin{tabular}{ccccc}
\hline & \multicolumn{4}{c}{ Mortality $(\% \pm \mathrm{SD})$} \\
\cline { 2 - 5 } $\begin{array}{c}\text { Concentration } \\
\left(\mathrm{mg} \mathrm{mL} \mathrm{m}^{-1}\right)\end{array}$ & $\begin{array}{c}\text { Foeniculum } \\
\text { vulgare }\end{array}$ & $\begin{array}{c}\text { Tagetes } \\
\text { coronopifolia }\end{array}$ & $\begin{array}{c}T . \\
\text { lemmonii }\end{array}$ & $\begin{array}{c}T . \\
\text { terniflora }\end{array}$ \\
\hline 10.0 & $92 \pm 0.84 \mathrm{a}$ & $100 \pm 0.00 \mathrm{a}$ & $98 \pm 0.45 \mathrm{a}$ & $100 \pm 0.00 \mathrm{a}$ \\
3.5 & $80 \pm 1.00 \mathrm{ab}$ & $96 \pm 0.89 \mathrm{a}$ & $92 \pm 0.84 \mathrm{ab}$ & $78 \pm 0.84 \mathrm{~b}$ \\
1.0 & $68 \pm 0.84 \mathrm{~b}$ & $70 \pm 0.71 \mathrm{~b}$ & $72 \pm 0.84 \mathrm{bc}$ & $62 \pm 0.84 \mathrm{~b}$ \\
0.35 & $52 \pm 0.84 \mathrm{c}$ & $64 \pm 0.89 \mathrm{~b}$ & $58 \pm 1.64 \mathrm{~cd}$ & $40 \pm 0.71 \mathrm{c}$ \\
0.1 & $44 \pm 0.55 \mathrm{~cd}$ & $48 \pm 0.84 \mathrm{c}$ & $56 \pm 1.14 \mathrm{~cd}$ & $38 \pm 0.84 \mathrm{c}$ \\
0.035 & $32 \pm 0.45 \mathrm{de}$ & $32 \pm 0.84 \mathrm{~d}$ & $46 \pm 1.34 \mathrm{de}$ & $34 \pm 1.14 \mathrm{c}$ \\
0.01 & $28 \pm 0.45 \mathrm{e}$ & $30 \pm 0.71 \mathrm{~d}$ & $36 \pm 0.89 \mathrm{de}$ & $30 \pm 0.71 \mathrm{c}$ \\
0.001 & - & - & $32 \pm 1.48 \mathrm{e}$ & $26 \pm 1.67 \mathrm{~cd}$ \\
Control & $4 \pm 0.55 \mathrm{f}$ & $4 \pm 0.55 \mathrm{e}$ & $6 \pm 0.55 \mathrm{f}$ & $6 \pm 0.55 \mathrm{~d}$ \\
\hline $\mathrm{X}^{2}$ & 37.15 & 37.19 & 38.27 & 37.51 \\
$\mathrm{LC}_{50}$ & 0.193 & 0.111 & 0.050 & 0.206 \\
& $(0.13-0.27)^{1}$ & $(0.04-0.25)$ & $0.01-0.15)$ & $(0.04-1.41)$ \\
$\mathrm{b} \pm \mathrm{s}$ & $0.6 \pm 0.05$ & $0.8 \pm 0.1$ & $0.7 \pm 0.1$ & $0.4 \pm 0.1$ \\
\hline
\end{tabular}

Means with different letters in the same column are significantly different according to Tukey's test $(\mathrm{p} \leq 0.05)$. SD: Standard deviation; $\mathrm{X}^{2}$ : Chi-square; $\mathrm{LC}_{50}$ : median lethal concentration; b: regression line slope; s: standard error.

${ }^{1}$ Confidence intervals, $95 \%$.

Table 3. Mean mortality ( $\% \pm$ SD) of Diaphorina citri adults 24 and $48 \mathrm{~h}$ after the application of three essential oils.

\begin{tabular}{|c|c|c|c|c|c|c|}
\hline \multirow{2}{*}{$\begin{array}{l}\text { Concentration } \\
\left(\mathrm{mg} \mathrm{mL}^{-1}\right)\end{array}$} & \multicolumn{2}{|c|}{ Foeniculum vulgare } & \multicolumn{2}{|c|}{ Tagetes coronopifolia } & \multicolumn{2}{|c|}{ T. terniflora } \\
\hline & $24 \mathrm{~h}$ & $48 \mathrm{~h}$ & $24 \mathrm{~h}$ & $48 \mathrm{~h}$ & $24 \mathrm{~h}$ & $48 \mathrm{~h}$ \\
\hline 100 & $100 \pm 0.00 \mathrm{a}$ & - & $100 \pm 0.00 \mathrm{a}$ & - & $100 \pm 0.00 \mathrm{a}$ & - \\
\hline 60 & $96 \pm 1.10 \mathrm{a}$ & $100 \pm 0.00 \mathrm{a}$ & $95 \pm 1.00 \mathrm{a}$ & $100 \pm 0.00 \mathrm{a}$ & $87 \pm 1.95 \mathrm{ab}$ & $90 \pm 1.41 \mathrm{a}$ \\
\hline 40 & $64 \pm 4.32 b$ & $80 \pm 3.74 a$ & $85 \pm 3.00 \mathrm{ab}$ & $96 \pm 0.84 \mathrm{ab}$ & $70 \pm 1.00 b c$ & $78 \pm 2.70 \mathrm{ab}$ \\
\hline 20 & $53 \pm 2.70 b$ & $72 \pm 4.62 \mathrm{ab}$ & $66 \pm 3.11 b$ & $79 \pm 1.92 b$ & $51 \pm 3.90 \mathrm{~cd}$ & $57 \pm 3.97 \mathrm{bc}$ \\
\hline 10 & $26 \pm 1.64 c$ & $45 \pm 3.81 b c$ & $24 \pm 1.30 c$ & $45 \pm 4.00 \mathrm{c}$ & $35 \pm 2.35 \mathrm{de}$ & $45 \pm 5.52 \mathrm{~cd}$ \\
\hline 3.5 & $13 \pm 1.95 \mathrm{~cd}$ & $22 \pm 2.51 \mathrm{~cd}$ & $8 \pm 1.52 \mathrm{~cd}$ & $20 \pm 1.58 \mathrm{~d}$ & $21 \pm 2.28 \mathrm{ef}$ & $22 \pm 1.95 \mathrm{de}$ \\
\hline 1.0 & $9 \pm 1.30 \mathrm{~cd}$ & $14 \pm 2.39 \mathrm{~cd}$ & - & - & $12 \pm 0.55 f$ & $12 \pm 0.89 \mathrm{e}$ \\
\hline Control & $0 \pm 0.00 \mathrm{~d}$ & $2 \pm 0.89 d$ & $2 \pm 0.89 d$ & $4 \pm 1.10 \mathrm{~d}$ & $3 \pm 0.89 f$ & $3 \pm 0.89 \mathrm{e}$ \\
\hline$X^{2}$ & 36.51 & 30.33 & 31.63 & 27.55 & 36.18 & 29.40 \\
\hline $\mathrm{LC}_{50}$ & 14.93 & 8.31 & 15.02 & 9.74 & 14.15 & 11.38 \\
\hline & $(6.27-31.53)^{1}$ & $(4.21-14.22)$ & $(11.57-18.89)$ & $(7.30-12.43)$ & $(7.82-24.09)$ & $(7.20-16.97)$ \\
\hline $\mathrm{b} \pm \mathrm{s}$ & $1.7 \pm 0.2$ & $1.6 \pm 0.2$ & $2.6 \pm 0.2$ & $2.6 \pm 0.2$ & $1.5 \pm 0.2$ & $1.6 \pm 0.2$ \\
\hline
\end{tabular}

Means with different letters in the same column are significantly different according to Tukey's test $(\mathrm{p} \leq 0.05)$.

SD: Standard deviation; $\mathrm{X}^{2}$ : Chi-square; $\mathrm{LC}_{50}$ : median lethal concentration; b: Regression line slope; s: standard error.

${ }^{1}$ Confidence intervals, $95 \%$.

the entire experiment. A repellent effect was observed at $3.5 \mathrm{mg} \mathrm{mL}^{-1}$ after 4 and $5 \mathrm{~h}$ of exposure (RI $=0.71 \pm 0.25$ and 0.75 \pm 0.18 , respectively) and up to $40 \mathrm{mg} \mathrm{mL}^{-1}$ at 6 and $24 \mathrm{~h}$ of exposure ( $0.06 \pm 0.09$ and $0.02 \pm 0.04$, respectively) (Table 5). The oil extract from T. terniflora exhibited $74 \%$ repellency levels at $40 \mathrm{mg} \mathrm{mL}^{-1}$ after a $4 \mathrm{~h}$ exposure; however, this effect decreased 5, 6 and $24 \mathrm{~h}$ after exposure with RI $0.62 \pm 0.21$ and $0.70 \pm 0.11\left(20 \mathrm{mg} \mathrm{mL}^{-1}\right)$ at 4 and $5 \mathrm{~h}$, respectively, 0.89 $\pm 0.07\left(10 \mathrm{mg} \mathrm{mL}^{-1}\right)$ at $6 \mathrm{~h}$, and $0.86 \pm 0.12\left(40 \mathrm{mg} \mathrm{mL}^{-1}\right)$ at $24 \mathrm{~h}$ (Table 6).

The $\mathrm{RC}_{50}$ values ranged from 3.05 to $42.16 \mathrm{mg} \mathrm{mL}^{-1}$. After a $4 \mathrm{~h}$ exposure, the oil extracts from $T$. lucida and $T$. coronopifolia had lower $\mathrm{RC}_{50}$ values ( 3.05 and $4.31 \mathrm{mg} \mathrm{mL}^{-1}$, respectively) than $T$. terniflora at the different evaluated periods. Oil extract activity decreased notably 5 and $6 \mathrm{~h}$ after exposure (Tables 4, 5, and 6). 
Table 4. Percentage (\%) of repellence of Diaphorina citri adults exposed to essential oil from Tagetes coronopifolia.

\begin{tabular}{|c|c|c|c|c|c|c|c|c|c|c|c|c|}
\hline \multirow{2}{*}{$\begin{array}{l}\text { Concentration } \\
\left(\mathrm{mg} \mathrm{mL}^{-1}\right)\end{array}$} & Rep. (\%) & \multirow{2}{*}{$\begin{array}{l}\mathrm{RI} \pm \mathrm{SE} \\
4 \mathrm{~h}\end{array}$} & \multirow[t]{2}{*}{$\mathrm{Cl}^{2}$} & Rep. (\%) & \multirow{2}{*}{$\begin{array}{l}\mathrm{RI} \pm \mathrm{SE} \\
5 \mathrm{~h}\end{array}$} & \multirow[t]{2}{*}{$\mathrm{Cl}$. } & Rep. $(\%)$ & \multirow{2}{*}{$\begin{array}{l}\mathrm{RI} \pm \mathrm{SE} \\
6 \mathrm{~h}\end{array}$} & \multirow[t]{2}{*}{$\mathrm{Cl}$. } & Rep. (\%) & $\mathrm{RI} \pm \mathrm{SE}$ & \multirow[t]{2}{*}{$\mathrm{Cl}$. } \\
\hline & & & & & & & & & & & $24 \mathrm{~h}$ & \\
\hline 40.0 & $92^{1}$ & $0.16 \pm 0.05$ & $\mathrm{R}$ & 81 & $0.33 \pm 0.18$ & $\mathrm{R}$ & 73 & $0.43 \pm 0.15$ & $\mathrm{R}$ & 60 & $0.57 \pm 0.41$ & $\mathrm{R}$ \\
\hline 20.0 & 62 & $0.58 \pm 0.23$ & $\mathrm{R}$ & 46 & $0.72 \pm 0.13$ & $\mathrm{R}$ & 35 & $0.79 \pm 0.16$ & $\mathrm{R}$ & 19 & $0.89 \pm 0.19$ & A \\
\hline 10.0 & 60 & $0.60 \pm 0.28$ & $\mathrm{R}$ & 53 & $0.66 \pm 0.21$ & $\mathrm{R}$ & 37 & $0.78 \pm 0.11$ & $\mathrm{R}$ & 18 & $0.90 \pm 0.09$ & $\mathrm{R}$ \\
\hline 3.5 & 45 & $0.74 \pm 0.23$ & $\mathrm{R}$ & 36 & $0.80 \pm 0.13$ & $\mathrm{R}$ & 27 & $0.85 \pm 0.09$ & $\mathrm{R}$ & 17 & $0.90 \pm 0.15$ & A \\
\hline 1.0 & 26 & $0.89 \pm 0.26$ & A & 22 & $0.90 \pm 0.09$ & $\mathrm{R}$ & 15 & $0.92 \pm 0.14$ & A & 12 & $0.93 \pm 0.09$ & A \\
\hline 0.35 & 35 & $0.82 \pm 0.31$ & A & 27 & $0.86 \pm 0.15$ & A & 13 & $0.94 \pm 0.05$ & $\mathrm{R}$ & 15 & $0.91 \pm 0.12$ & A \\
\hline 0.1 & 28 & $0.87 \pm 0.19$ & A & 21 & $0.90 \pm 0.16$ & A & 16 & $0.92 \pm 0.08$ & $\mathrm{~N}$ & 10 & $0.94 \pm 0.10$ & A \\
\hline Control & 8 & & & 5 & & & 2 & & & 0 & & \\
\hline $\begin{array}{l}\mathrm{RC}_{50} \\
\mathrm{~b} \pm \mathrm{s}\end{array}$ & & $\begin{array}{l}1(1.06-28.91)^{3} \\
0.65 \pm 0.1\end{array}$ & & 10.76 & $\begin{array}{l}6(3.14-167 . \\
0.58 \pm 0.1\end{array}$ & & & $\begin{array}{c}14(7.21-448 \\
0.59 \pm 0.1\end{array}$ & & & - & \\
\hline
\end{tabular}

Rep: Repellence; RI: repellence index; SE: standard error; $\mathrm{RC}_{50}$ : median repellence concentration; b: regression line slope; s: standard error. ${ }^{1}$ Percentage of repellence taken from real data.

${ }^{2}$ Classification: R: repellent; N: neutral; A: attractant.

${ }^{3}$ Confidence intervals, $95 \%$.

Table 5. Percentage (\%) of repellence of Diaphorina citri adults exposed to essential oil from Tagetes lucida.

\begin{tabular}{|c|c|c|c|c|c|c|c|c|c|c|c|c|}
\hline \multirow{2}{*}{$\begin{array}{l}\text { Concentration } \\
\left(\mathrm{mg} \mathrm{mL}^{-1}\right)\end{array}$} & Rep. (\%) & \multirow{2}{*}{$\begin{array}{l}\mathrm{RI} \pm \mathrm{SE} \\
4 \mathrm{~h}\end{array}$} & \multirow[t]{2}{*}{$\mathrm{Cl}^{2}$} & Rep. (\%) & $\mathrm{RI} \pm \mathrm{SE}$ & \multirow[t]{2}{*}{$\mathrm{Cl}$. } & Rep. (\%) & $\mathrm{RI} \pm \mathrm{SE}$ & \multirow[t]{2}{*}{$\mathrm{Cl}$. } & Rep. (\%) & $\mathrm{RI} \pm \mathrm{SE}$ & \multirow[t]{2}{*}{$\mathrm{Cl}$. } \\
\hline & & & & \multicolumn{2}{|r|}{$5 \mathrm{~h}$} & & \multicolumn{2}{|r|}{$6 \mathrm{~h}$} & & \multicolumn{2}{|r|}{$24 \mathrm{~h}$} & \\
\hline 40.0 & $99^{1}$ & $0.02 \pm 0.04$ & $\mathrm{R}$ & 97 & $0.06 \pm 0.09$ & $\mathrm{R}$ & 97 & $0.06 \pm 0.09$ & $\mathrm{R}$ & 99 & $0.02 \pm 0.04$ & $\mathrm{R}$ \\
\hline 20.0 & 85 & $0.28 \pm 0.27$ & $\mathrm{R}$ & 69 & $0.48 \pm 0.37$ & $\mathrm{R}$ & 63 & $0.55 \pm 0.45$ & $\mathrm{~N}$ & 49 & $0.69 \pm 0.33$ & A \\
\hline 10.0 & 57 & $0.64 \pm 0.30$ & $\mathrm{R}$ & 37 & $0.79 \pm 0.15$ & $\mathrm{R}$ & 30 & $0.83 \pm 0.25$ & A & 17 & $0.92 \pm 0.17$ & A \\
\hline 3.5 & 49 & $0.71 \pm 0.25$ & $\mathrm{R}$ & 42 & $0.75 \pm 0.18$ & $\mathrm{R}$ & 29 & $0.84 \pm 0.26$ & A & 19 & $0.91 \pm 0.15$ & A \\
\hline 1.0 & 34 & $0.84 \pm 0.16$ & $\mathrm{~N}$ & 21 & $0.90 \pm 0.15$ & A & 21 & $0.89 \pm 0.17$ & A & 22 & $0.89 \pm 0.25$ & A \\
\hline 0.35 & 25 & $0.90 \pm 0.27$ & A & 19 & $0.91 \pm 0.19$ & A & 12 & $0.95 \pm 0.15$ & A & 15 & $0.93 \pm 0.07$ & $\mathrm{~N}$ \\
\hline 0.1 & 23 & $0.91 \pm 0.27$ & A & 14 & $0.94 \pm 0.16$ & A & 9 & $0.96 \pm 0.13$ & A & 14 & $0.94 \pm 0.23$ & A \\
\hline Control & 9 & & & 4 & & & 3 & & & 4 & & \\
\hline $\mathrm{RC}_{50}$ & \multirow{2}{*}{\multicolumn{3}{|c|}{$\begin{array}{c}3.05(1.09-9.16)^{3} \\
0.9 \pm 0.1\end{array}$}} & \multirow{2}{*}{\multicolumn{3}{|c|}{$\begin{array}{c}6.12(1.81-37.34) \\
0.9 \pm 0.2\end{array}$}} & \multirow{2}{*}{\multicolumn{3}{|c|}{$\begin{array}{c}8.91(2.76-70.19) \\
1.0 \pm 0.2\end{array}$}} & \multirow{2}{*}{\multicolumn{3}{|c|}{ - }} \\
\hline$b \pm s$ & & & & & & & & & & & & \\
\hline
\end{tabular}

Rep: Repellence; RI: repellence index; SE: standard error; $\mathrm{RC}_{50}$ : median repellence concentration; b: regression line slope; s: standard error. 'Percentage of repellence taken from real data.

${ }^{2}$ Classification: R: repellent; N: neutral; A: attractant.

${ }^{3}$ Confidence intervals, $95 \%$.

Table 6. Percentage $(\% \pm \mathrm{SE})$ of repellence of Diaphorina citri adults exposed to essential oil from Tagetes terniflora.

\begin{tabular}{|c|c|c|c|c|c|c|c|c|c|c|c|c|}
\hline \multirow{2}{*}{$\begin{array}{l}\text { Concentration } \\
\left(\mathrm{mg} \mathrm{mL}^{-1}\right)\end{array}$} & Rep. (\% & 6) $\mathrm{RI} \pm \mathrm{SE}$ & $\mathrm{Cl}^{2}$ & Rep. $(\%)$ & 6) $\mathrm{RI} \pm \mathrm{SE}$ & $\mathrm{Cl}$. & Rep. (\%) & $\mathrm{RI} \pm \mathrm{SE}$ & $\mathrm{Cl}$. & Rep. (\%) & $\mathrm{RI} \pm \mathrm{SE}$ & $\mathrm{Cl}$. \\
\hline & \multicolumn{3}{|c|}{$4 \mathrm{~h}$} & \multicolumn{3}{|c|}{$5 \mathrm{~h}$} & \multicolumn{3}{|c|}{$6 \mathrm{~h}$} & \multicolumn{3}{|c|}{$24 \mathrm{~h}$} \\
\hline 40.0 & $74^{1}$ & $0.45 \pm 0.18$ & $\mathrm{R}$ & 63 & $0.56 \pm 0.19$ & $\mathrm{R}$ & 43 & $0.73 \pm 0.23$ & $\mathrm{R}$ & 25 & $0.86 \pm 0.12$ & $\mathrm{R}$ \\
\hline 20.0 & 60 & $0.62 \pm 0.21$ & $\mathrm{R}$ & 49 & $0.70 \pm 0.11$ & $\mathrm{R}$ & 36 & $0.79 \pm 0.13$ & $\mathrm{R}$ & 24 & $0.86 \pm 0.15$ & A \\
\hline 10.0 & 34 & $0.85 \pm 0.22$ & A & 30 & $0.85 \pm 0.16$ & A & 20 & $0.89 \pm 0.07$ & $\mathrm{R}$ & 11 & $0.94 \pm 0.13$ & A \\
\hline 3.5 & 34 & $0.85 \pm 0.16$ & A & 27 & $0.87 \pm 0.25$ & A & 16 & $0.92 \pm 0.15$ & A & 11 & $0.94 \pm 0.18$ & A \\
\hline 1.0 & 23 & $0.92 \pm 0.23$ & A & 22 & $0.90 \pm 0.34$ & A & 11 & $0.95 \pm 0.27$ & A & 8 & $0.96 \pm 0.09$ & $\mathrm{~A}$ \\
\hline 0.35 & 17 & $0.96 \pm 0.11$ & A & 14 & $0.95 \pm 0.18$ & A & 12 & $0.94 \pm 0.09$ & A & 9 & $0.95 \pm 0.08$ & A \\
\hline 0.1 & 17 & $0.96 \pm 0.05$ & A & 20 & $0.91 \pm 0.16$ & A & 11 & $0.95 \pm 0.08$ & A & 8 & $0.96 \pm 0.13$ & A \\
\hline Control & 11 & & & 6 & & & 2 & & & 1 & & \\
\hline \multirow[t]{2}{*}{$\mathrm{RC}_{50}$} & & $\begin{array}{c}18.59 \\
(8.32-76.72)^{3}\end{array}$ & & & $\begin{array}{c}42.16 \\
(11.14-2779)\end{array}$ & & & - & & & - & \\
\hline & & $0.8 \pm 0.1$ & & & $0.55 \pm 0.1$ & & & & & & & \\
\hline
\end{tabular}

Rep: Repellence; RI: repellence index; SE: standard error; $\mathrm{RC}_{50}$ : median repellence concentration; b: regression line slope; s: standard error. 'Percentage of repellence taken from real data.

${ }^{2}$ Classification: R: repellent; N: neutral; A: attractant.

${ }^{3}$ Confidence intervals, $95 \%$. 


\section{DISCUSSION}

The findings of the present study reveal toxic and repellent effects of essential oil extracts from $F$. vulgare, T. coronopifolia, and $T$. lemmonii against $D$. citri nymphs and adults, and $T$. terniflora only against nymphs. Our results confirm previous reports by other authors who studied their effects against other pests. They observed that extracts from Tagetes in nonpolar solvents were more toxic than water-soluble extracts (Camarillo et al., 2009). This effect was attributed to the fact that the oil extracts removed the wax from the insect cuticle, thus causing the dehydration of membrane cells and their death (Regnault-Roger et al., 2012).

The variation in the response of $D$. citri to different oil extracts is also related to the composition and structure of the active ingredients. In the present study, 18 to 31 compounds were identified in each of the plants, including verbenone, $\beta$-ocimene, anethole, and tagetone, which are compounds shared by the Tagetes species and $F$. vulgare. These compounds have shown broad-spectrum insecticide activity against varied insect pests due to the presence of diverse active molecules, each one with a different mode of action (Camarillo et al., 2009; Gillette et al., 2009). It is important to indicate that some of the compounds identified in the essential oils from the evaluated plant species in our study have shown insecticide synergistic activity between major and minor constituents as well as high yield; such plants have been proposed as alternative crops to integrate a strategy for a more extensive use of natural substances in the field (Tak and Isman, 2015).

The efficacy of oil extracts is also influenced by their persistence in the environment over time, as noted by Cubillo et al. (1999). They mention that fatty extracts are more effective, mainly due to the presence of insecticide compounds, their persistence on the plant, and their contact activity on the insect cuticle. Based on the molecules found in the oil extracts evaluated in the present study, trans-anethole was previously identified for its role in insect pest control (Xu et al., 2012; Zoubiri et al., 2014). Camarillo et al. (2009) observed that oils extracted by hydrodistillation from Tagetes filifolia Lag. (Asteraceae) were more effective (more repellent, toxic, and inhibitive of oviposition and growth) against Trialeurodes vaporariorum West. than aqueous extracts. This was due to differences in composition and concentration of active ingredients such as trans-anethole, allylanisole, $\beta$-caryophyllene, and tagetone, which we also demonstrated in our study with the results for the Tagetes species and F. vulgare. Although it is known that the oil extracts from T. filifolia and T. coronopifolia have a high proportion of trans-anethole, there is still scarce information about the relationship between this and other compounds in the oil from different Tagetes species (Serrato et al., 2008; Mendoza-García et al., 2015).

In the present study, the length of time that $D$. citri adults were exposed to the oil extracts had a major influence on mortality. This finding is similar to studies by Cázares et al. (2014), who found high mortality (70.31\%) of D. citri adults when exposed for $48 \mathrm{~h}$ to the oil extracts from Lippia graveolens Kunth (Verbenaceae) at a $40 \mathrm{mg} \mathrm{mL}^{-1}$ concentration. The insect development stage and product application mode are other factors that need further detailed evaluation to improve the potential for insect pest control (Zoubiri et al., 2014).

The repellent effect of plant essential oils against $D$. citri found in the present study suggests that it may be due to the inherent characteristics and chemical composition of oils. For example, Davison et al. (1991) found that oil viscosity and density determined their weight and retention time on leaves. The repellent substances are therefore gradually released and delay insect arrival on treated plants. Moreover, the action of the evaluated oils depends on the fact that there are multiple active substances present in the plants that function on the insects in different ways (Poerwanto et al., 2012). Wright (1975) stated that the repellent activity and persistence of oils depended on the size and shape of the active molecules within each product, as well as on their assembly and persistence in the sensorial receptors of insect antennae. The instability of the oil extracts over time that was found in the present study confirms reports by other authors working with B. tabaci (Cubillo et al., 1999) and T. vaporariorum (Camarillo et al., 2009). This was attributed to the rapid compound breakdown by environmental and biological factors, such as UV radiation, temperature, $\mathrm{pH}$, and microbial activity. However, repellent activity can be recovered over time by temporal immediate or gradual saturation and desaturation processes of the insect chemoreceptors to produce a variable response (Wright, 1975). Microencapsulation of essential oils could be a useful way for controlling the release of active components (López et al., 2014). The application of the correct concentration to achieve a repellent effect against $D$. citri is also important. As seen with the RI values, concentrations less than 3.5 $\mathrm{mg} \mathrm{mL}^{-1}$ cause the opposite effect to what was expected, a characteristic also reported by Camarillo et al. (2009) and Mendoza-García et al. (2014) with T. vaporariorum. They reported that low rates of oil extracts from T. filifolia, aqueous extracts from Taraxacum officinale (Asteraceae) Weber, and ethanol extracts of Raphanus raphanistrum L. (Brassicaceae) 
stimulated insect oviposition. This suggests that studies should be continued at the molecular level to identify activity sites in the insect and fully recognize their beneficial effects for the different molecules found in the studied species (Poerwanto et al., 2012). For example, verbenone contained in T. coronopifolia and T. terniflora has been reported as having repellent activity against insect pests (Gillette et al., 2009). It has been approved by the U.S. Food and Drug Administration as a food additive and is currently approved by the U.S. Environmental Protection Agency (US EPA) as a biopesticide for forestry use. Currently registered formulations include pouches (several registrants), Disrupt Micro-Flake VBN, Disrupt BioFlake VBN, and Disrupt Bio-Dispenser BB (Hercon Environmental). Based on recent research innovations, MafraNeto et al. (2015) developed a botanically derived repellent identified from guava leaves. This compound, dimethyl disulfide (DMDS), was formulated as SPLAT ACPRepel, which has shown great potential in field trials to reduce D. citri in infested citrus orchards and reduce Huanglongbing infection rates.

\section{CONCLUSIONS}

Some 18 to 31 compounds were identified in the seven essential oils obtained from the evaluated plant species; anethole, verbenone, 4-ethyl-4-methyl-1-hexene, 4-allylanisole, and trans-tagetone were abundant. Oils from the Tagetes species shared $\beta$-ocimene, 4-ethyl-4-methyl-1-hexene, anethole, trans-tagetone, cis-tagetone, verbenone, cis-verbenone, and $\beta$-caryophyllene. Oil extracts from the Foeniculum vulgare and Tagetes species were toxic and/or repellent to both adults and nymphs and the activity was correlated with the concentration. Extracts from F. vulgare, T. coronopifolia, T. lemmonii and T. terniflora could be important potential alternatives to synthetic pesticides for the management of Diaphorina citri.

\section{ACKNOWLEDGEMENTS}

This work was supported by the project FONSEC-SAGARPA-CONACYT 2009-108591. Thanks are also due to CONACYT for the scholarship granted for the PhD studies of the first author.

\section{REFERENCES}

Bové, J.M. 2012. Huanglongbing and the future of citrus in Sao Paulo State, Brazil. Journal of Plant Pathology 94:465-467.

Calderón, R.G., y Rzedowski, J. 2001. Flora fanerogámica del Valle de México. $2^{a}$ ed. 1406 p. Instituto de Ecología, A.C., Veracruz, México.

Camarillo, G., Ortega, L.D., Serrato, M.A., y Rodríguez, C. 2009. Actividad biológica de Tagetes filifolia (Asteraceae) en Trialeurodes vaporariorum (Hemiptera: Aleyrodidae). Revista Colombiana de Entomología 35:177-184.

Cázares, A.N., Verde, S.M., López, A.J., y Almeyda, L.I. 2014. Evaluación de diferentes extractos vegetales contra el psílido asiático de los cítricos Diaphorina citri (Hemiptera: Liviidae). Revista Colombiana de Entomología 40:67-73.

Cubillo, D., Sanabria, G., y Hilje, L. 1999. Evaluación de repelencia y mortalidad causada por insecticidas comerciales y extractos vegetales sobre Bemisia tabaci. Manejo Integrado de Plagas 53:65-72.

Davison, N., Dibble, J., Flint, M., Marer, P., and Guye A. 1991. Managing insects and mites with sprays oils. University of California Integrated Pest Management Program Vol. 3347. 47 p. IPM Education and Publications, Statewide Integrated Pest Management Project, University of California, Division of Agriculture and Natural Resources, Davis, California, USA.

García-Méndez, V.H., Ortega-Arenas, L.D., Villanueva-Jiménez, J.A., y Sánchez-Arroyo, H. 2016. Susceptibilidad de Diaphorina citri Kuwayama (Hemiptera: Liviidae) a insecticidas en Veracruz, México. Agrociencia 50:355-365.

Gillette, N.E., Erbilgin, N., Webster, J.N., Pederson, L., Mori, S.R., Stein, J.D., et al. 2009. Aerially applied verbenone-releasing laminated flakes protect Pinus contorta stands from attack by Dendroctonus ponderosae in California and Idaho. Forest Ecology and Management 257:1405-1412.

Isman, M.B., Wilson, J.A., and Bradbury, R. 2008. Insecticidal activities of commercial rosemary oils (Rosmarinus officinalis) against larvae of Pseudaletia unipuncta and Trichoplusia $n i$ in relation to their chemical compositions. Pharmaceutical Biology 46:82-87.

López, A., Castro, S., Andina, M.J., Ures, X., Munguía, B., Llabot, J.M., et al. 2014. Insecticidal activity of microencapsulated Schinus molle essential oil. Industrial Crops and Products 53:209-216.

Mafra-Neto, A., Fettig, Ch.J., Munson, A.S., and Stelinsky, L.L. 2015. Use of repellents formulated in specialized pheromone and lure application technology for effective insect pest management, Chapter 16. p. 291-308. In Debboun, M., Frances, S., and Strickman, D. (eds.) Insect repellents handbook. CRC Press Taylor \& Francis Group, Boca Raton, Florida, USA. 
Mann, R.S., Tiwari, S., Smoot, J.M., Rouseff, L.R., and Stelinski, L.L. 2012. Repellency and toxicity of plant-based essential oils and their constituents against Diaphorina citri Kuwayama (Hemiptera: Psyllidae). Journal of Applied Entomology 136:1-10.

Mendoza-García, E.E., Ortega-Arenas, L.D., Pérez-Pacheco, R., and Rodríguez-Hernández, C. 2014. Repellency, toxicity, and oviposition inhibition of vegetable extracts against greenhouse whitefly Trialeurodes vaporariorum (Westwood) (Hemiptera: Aleyrodidae). Chilean Journal of Agricultural Research 74:41-48.

Mendoza-García, E.E., Ortega-Arenas, L.D., Serrato-Cruz, M.A., Díaz, C.F., Villanueva-Jiménez, J.A., López, J.I., et al. 2015. Efecto biológico del aceite de Tagetes coronopifolia (Asteraceae) contra Diaphorina citri (Hemiptera: Liviidae). Revista Colombiana de Entomología 41:157-162.

Poerwanto, M.E., Trisyono, A.Y., Beattie, C.A., Subandiyah, S., Martono, E., and Holford, P. 2012. Olfactory responses of the Asiatic citrus psyllid (Diaphorina citri) to mineral oil-treated mandarin leaves. American Journal of Agricultural and Biological Sciences 7:50-55

Regnault-Roger, C., Vincent, Ch., and Arnason, J.T. 2012. Essential oils in insect control: Low-risk products in a high-stakes world. Annual Review of Entomology 57:405-424.

Serrato, C.M., Díaz, F.C., y Barajas, P.J. 2008. Composición en el aceite esencial en germoplasma de Tagetes filifolia Lag. de la región centro-sur de México. Agrociencia 42:277-285.

Shamkant, B.B., Vaishnav, V.P., and Atmaram, H.B. 2014. Foeniculum vulgare Mill: A review of its botany, phytochemistry, pharmacology, contemporary application, and toxicology. BioMed Research International 2014:ID842674. 32 p. doi:10.1155/2014/842674.

Stansly, P.A., and Qureshi, J.A. 2007. Insecticidal control of Asian citrus psyllid through foliar applications on orange, 2006. Arthropod Management Tests 32(1):D10. https://doi.org/10.1093/amt/32.1.D10.

Tak, J.H., and Isman, B.M. 2015. Enhanced cuticular penetration as the mechanism for synergy of insecticidal constituents of rosemary essential oil in Trichoplusia ni. Scientific Reports 5:12690. doi:10.1038/srep12690.

Tiwari, S., Stelinski, L.L., and Rogers, M.E. 2012. Biochemical basis of organophosphate and carbamate resistance in Asian citrus psyllid. Journal of Economic Entomology 105:540-548.

Wright, R.H. 1975. How mosquito repellents repel? Scientific American 233:104-111.

Xu, L.W., Chen, J., Qi, H.Y., and Shi, Y.P. 2012. Phytochemicals and their biological activities of plants of Tagetes L. Chinese Herbal Medicine 4:103-117.

Zoubiri, S., Baaliouamer, A., Seba, N., and Chamouni, N. 2014. Chemical composition and larvicidal activity of Algerian $F$. vulgare seed essential oil. Arabian Journal of Chemistry 7:480-485. 